\title{
MULTI CRITERIA PREVENTIVE MAINTENANCE SCHEDULING THROUGH ARENA BASED SIMULATION MODELING
}

\author{
Gonca Altuger \\ Constantin Chassapis \\ Department of Mechanical Engineering \\ Stevens Institute of Technology \\ Castle Point on Hudson \\ Hoboken, NJ, 07030, USA
}

\begin{abstract}
Line performance and equipment utilization have been major points of interest for many companies due to their direct impact on productivity. Achieving the highest possible utilization while maximizing throughput will improve the line performance; will also show significant increase on the line productivity. There are many variables that affect the line utilization and performance and preventive maintenance schedule is one of them. In this paper a multi criteria decision making approach will be implemented to select the preventive maintenance schedule that gives the best utility and performance values. To demonstrate the selection process a bread packaging line is used as a case study. Environmental conditions and line behavior are developed and simulated by using an Arena-based simulation model. The Arena model is to be used as a support tool for the multi criteria decision making process.
\end{abstract}

\section{INTRODUCTION}

The importance of line performance and utilization was increased as competitiveness of the global market place is forcing companies to look for ways to more efficiently utilize their existing production lines especially when considering new product introduction. Even though increasing line utilization and performance can be done through various costly ways such as; replacing the existing machines and stations with new ones, it is not always financially feasible to replace the whole line. Instead companies have started to look into improving the reliability of the existing line so that the downtimes are minimum and the machine reliability levels are under control. One way to do that is to focus on the preventive maintenance scheduling. Dekker (1996) summarized the maintenance objectives under four headings as: ensuring system function (availability, efficiency and production quality), ensuring system life (asset management), ensuring safety and ensuring human well-being; and suggested that for production equipment, ensuring the system function should be the prime objective where the prime maintenance objective is to provide the right reliability, availability, efficiency and capability. Among those objectives, providing the right system reliability gained more importance, the first Reliability Centered Maintenance (RCM) approach was developed and published by Matteson, Nowlan, Heap and several other United Airlines engineers with a goal of achieving the optimum maintenance needs for an aircraft. Production scheduling and preventive maintenance (PM) planning decisions and activities are inter-dependent, even though most of the time they are performed independently (Cassady and Kutanoglu 2003, 2005). With the goal of obtaining optimum preventive maintenance (PM) scheduling researchers have utilized queuing theory approaches when determining the order of maintenance in a manufacturing line, such as; first in first out (FIFO), last in first out (LIFO), serve in random order (SIRO), and priority queuing (PQ). Priority queuing lead engineers to develop priority based maintenance schedules. A system value based method (SVB) was proposed by (Yang et al. 2007) where value of the system is being measured by the shortest time to finish for each station, and the "value" of the stations close to the end of the line are higher than the ones in the beginning of the line. With this approach, they assigned preventive maintenance priorities to each station and machine. The station with the highest value was the first machine to get preventive maintenance.

Setting up a schedule for a production line is not always easy. Predicting the outcome of the scheduling without running the line creates a certain level of uncertainty for the design engineers. Newer technological developments have enabled the use of simulation models to test the performance of the manufacturing lines even before they exist, and define and implement the scheduling. Various researchers have reported significant benefits from the use of simulation based models for process improvement, scheduling, and scenario comparisons. In a recent study (Adams et al. 1999) two case studies are examined to show how simulation supports the continuous process improvement. A real world semiconductor example was discussed to highlight the extra benefits received from implementing simulation at a semiconductor manufacturing plant (Hickie and Fow- 


\section{Altuger and Chassapis}

ler 1999). In Harrell and Gladwin (2007) an application was presented in which simulation was used to identify the bottleneck of a dishwasher tub manufacturing line, where the engineers were then able to determine and verify a solution to the bottleneck which resulted in an annual savings of $\$ 275,000$. There are different ways of building and performing simulations. A recent study (Al-Aomar 2000) stated that with the aid of discrete-event simulations, companies were able to design efficient production and business systems, validate and tradeoff proposed design solution alternatives, troubleshoot potential problems, improve system performance metrics, and, consequently, cut cost, meet targets, and boost sales and profits. An outline was provided in their study by Knoll and Heim (2000) for the companies to determine if or when they need to adapt discrete-event simulation in their manufacturing environments. In a discrete event simulation model (Sharda and Bury 2008) which was developed to identify and understand the impact of different failures on the overall production capabilities in a chemical plant, concluded that the present work shows the potential of discrete event simulation for such applications. In Chong, Sivakumar, and Gay (2003) a simulation-based real-time manufacturing mechanism for dynamic discrete manufacturing was presented, where the basic idea of the mechanism is to engage discrete event simulation to combine different scheduling approaches based on the past performance. A real-world application of the iterative use of simulation results as an input to scheduling was presented by (Vasudevan et al. 2008), where the schedules generated used as a simulation input parameter, where iterative use of simulation and scheduling presented a powerful technique for making all-round productivity improvement recommendations. Johansson and Kaiser (2002) examined that to what extent discrete event simulation can be applied to the evaluation of resetting performance in manufacturing systems, where a discrete event simulation model of a factory unit in Sweden is used as a case study; their outcomes suggested that there is a large potential to increase the productivity in the manufacturing model by implementing the findings from the discrete event simulation model into the manufacturing system. Seppanen (2005) described an Arena-based operator-paced assembly line simulation model, where the model presented demonstrated the feasibility of including intermittent operator duties in addition to the standard assembly line paced duties. In Kelton, Sadowski and Sadowski (2002) several case studies provided for discrete event simulation processes in their book along with techniques and tutorials on building Arena models. Production engineers and managers benefit from the simulation applications as they mimic the line behavior, to perform extended analyses and to compare different scenarios. This is clearly illustrated by McLean and Shao (2003), where they stated that manufacturing managers commission simulation case studies to support their decision-making processes.

The objective of the study presented in this paper is to benefit from discrete event simulations to assess different preventive maintenance scheduling techniques, and to incorporate simulations as a decision-making support tool to the decision process. In this paper, the authors consider the outcomes of three different preventive maintenance techniques for a packaging line. Arena simulation software is used throughout the study to define the packaging line machines' characteristic and to mimic the line behavior under different preventive maintenance schedules given different reliability constraints. The outcome results from all three preventive maintenance techniques are then compared with respect to system criteria to obtain the most suitable preventive maintenance technique for the case study.

\section{SIMULATION BASED PREVENTIVE MAINTENANCE SCHEDULE DEVELOPMENT}

The purpose of this case study is to provide a decision-making method when selecting the preventive maintenance schedule and to demonstrate how the Arena software's packaging module can be used to simulate and analyze an existing packaging line, including how the simulation model is prepared and run and how the outcomes of the simulation process can be used as an input data for preventive maintenance schedule selection. A bread manufacturing facility is used as a demonstrative example. The performance of the equipment will be individually examined as their reliability levels are individually set for each of the different preventive maintenance schedules. The line is made up of series and parallel connected packaging machines as shown in Figure 1. The bread loaves arrive to the packaging line, and go to the slicer station (station one). After they are sliced, they move to the shrink wrap (station two) station. Shrink wrapping is a crucial process in keeping the freshness of the bread for longer periods. The shrink wrap machine uses a food grade film, takes the sliced bread loaves in and discharges a fully wrapped package. Once the shrink wrap process is completed, the sliced and wrapped bread loaves arrive to the weighting stations (stations three and four). In this packaging facility there are two weighting stations connected in parallel to each other. The incoming parts either go to station three or four based on availability. The weighting station weights each loaf and marks the weight values on the shrink wrap as well as records the data for future statistical analysis and results. Once the loaves are weighted then they are transferred to the vertical filling station (station five), where they are vertically inserted into the plastic bags. Once the loaves are inserted into the plastic bags, they leave the vertical filling station and arrive to the sealing stations (station six and seven). Like the weighting stations, sealing machines are also parallel connected. Once the plastic bags are sealed, they are moved to the last station in the line, the labeling and boxing station (station eight). In the labeling station, nutritional information, expiration date, barcode, company name and brand name along with the facts and standards are printed on the packages. Once the loaves got labeled, they are placed in cartoons that held 12 bags each, and once they are boxed, they leave the packaging line for shipment. 


\section{Altuger and Chassapis}

In this packaging process, due to machine failures and preventive maintenance stoppages, lines can form in between the stations. In any case when a line forms, the parts follow the first in first out (FIFO) queuing theory principle. There are also two buffers located in this system, with a fixed buffer capacity.

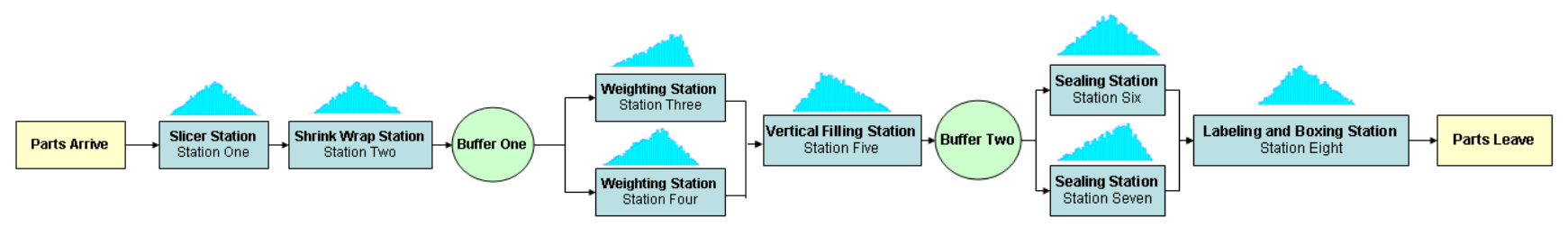

Figure 1: Bread packaging line layout

\subsection{Problem Definition}

Proper preventive maintenance schedules in production lines require high attention as they have major impacts on line performance, reliability and utilization. There are different approaches of setting a preventive maintenance schedules leading to different performance, reliability and utilization levels. For this example case, three different preventive maintenance scheduling and ordering methods are being considered: Global Maintenance Order (GMO), Reliability Maintenance Order (RMO) and Value-Based Maintenance Order (VMO). To quantify the outcomes of each approach, and to observe the line behavior an Arena-based simulation model will be built and run for each preventive maintenance scheduling technique. The outcomes (performance, utilization, time and cost) of the three techniques will then be compared and a multi criteria decision making analysis to facilitate the selection of the most desirable preventive maintenance (PM) scheduling technique. Each PM techniques will be run for three different minimum allowable reliability levels; $85 \%, 90 \%$ and $95 \%$. These are the reliability levels required for each individual station to reach before undergoing a scheduled PM. Difference in reliability levels will lead to differences in the time needed between PMs, which ,in turn, change the overall line reliability, line performance, utilization, cost and time parameters. Considering different reliability levels will provide an insight on how the line responds to that particular PM technique and will provide more broader data when performing a multi criteria decision making process to select which PM technique should be used for the considered packaging line.

Global Maintenance Order (GMO): The basic assumption of the GMO is to stop the packaging line altogether and perform preventive maintenance on each station whenever scheduling dictates such an action. Once preventive maintenance is completed at all the stations, then the line starts again and runs until the next scheduled preventive maintenance stoppage. The order of the maintenance does not matter, since none of the machines start working until the PM is over.

Reliability-Based Maintenance Order (RMO): Reliability-Based Maintenance Order (RMO) assigns preventive maintenance schedules and order depending on the station reliability levels. The method assumes that all station carry $100 \%$ (or any other value) reliability when the line first starts and decreases over time with a probabilistic distribution (which could be specified separately for each station). The design engineer sets the minimum acceptable reliability level for all stations individually, and stations go under preventive maintenance as they reach their minimum allowable reliability level. Since stations in a production line may have different probabilistic distributions attached to them, and since processing time for each station may be different, the line doesn't get stopped all at once. The order of maintenance is dependent on the machine reliability and time to perform PM. Machine reliabilities for any given time will be calculated using Equation 1, where R(t) denotes the reliability of a station at time $t$, where $\lambda$ is the distribution parameter and can be obtained from station's lifetime as shown in Equation 2. Mean Time to Fail (MTTF) denotes the mean time before a station fails and based on machine's life time distributions and time between failures. Once the individual station reliabilities are obtained, the overall system reliability can be calculated by using Equation 3 .

$$
\begin{gathered}
R(t)=e^{-\int \frac{t}{0} d t} \\
R(t)=e^{-\lambda t} \\
M T T F=\frac{1}{\lambda} \\
R_{\text {line }}=R_{1} * R_{2} *\left(1-\left(1-R_{3}\right) *\left(1-R_{4}\right)\right) * R_{5} *\left(1-\left(1-R_{6}\right) *\left(1-R_{7}\right)\right) * R_{8}
\end{gathered}
$$

Value-Based Maintenance Order (VMO): Value-Based Maintenance Order (VMO) is built based on the value method, where each station carries a value. The station values can be defined and calculated differently for different applications, such as; time to finish, processing time, good units produced, etc.... Generally the station close to the end of line is assumed to carry higher values then the stations close to the beginning of the line. Final station value $\left(\mathrm{V}_{\mathrm{i}}\right)$ is calculated by 


\section{Altuger and Chassapis}

subtracting the product of Total Parts Lost (TPL) in that station and the penalty value for each lost product from the product of Total Parts Processed (TPP) in that station and the value of each part reach that station, as shown in Equation 4.

$$
V_{i}=\left(T P P \_i n \_S t a t i o n\right)_{i} *(\text { Value_of_Station })_{i}-\left(T P L_{-} \text {in_Station }\right)_{i} *(\text { Penalty_Value_of_Station })_{i}
$$

\subsection{Building the Model}

In order to generate results for the different maintenance approaches, a computer based simulation model is used. Even though there are various software available to carry the needed simulation, the Arena simulation software package provided (Arena's Factory Analyzer module offers the Packaging template) the most suitable templates for the case study at hand. The Arena model, shown in Figure 2, is built based on the facility layout provided in Figure 1. All packaging stations are built using the machine module (line start, process and line stop), where the "Parts Arrive" and "Parts Leave" signify the beginning of the line and end of the line, respectively. By using the machine module, each station's reliability along with failure distributions, repair times, number of units lost after failures as well as scheduled stops (time before stop and stop duration) for preventive maintenance can be defined, as shown in Figure 3. Machine links are used to link any two machines together in the layout, they do not carry any properties, and they do not affect the outcome result. The model, involves two buffers, both of which are defined via the Conveyor module. Since the Arena Packaging Template does not offer buffer modules, a conveyor module is employed to mimic the behavior of a buffer by appropriately adjusting its size and speed as shown in Figure 4 (Regions A\&B of Figure 2). The material handling portions of the line are modeled using the conveyor module, where the run speed and conveyor properties are defined accordingly. Before each of the parallel connected station sets, a split module is used to divide the incoming parts into two. An adjustable splitting option is selected to maximize the system performance and utilization for both split stations. Once the parts leave the parallel connected stations, they are combined together with the Merge module. Finally a separate simulation module is placed in the model, to trigger the simulation for the packaging line simulation. This module helps the design engineer to determine which statistics will be measured, for this case study machines and conveyors statistics will be collected. Prior to running the simulation, run parameters are defined; no warm up period is defined for any of the machines, and the replication length is set to 3840 hours, which equals to one year's processing times for the machines, 20 days/monthly, 2 shifts/daily, and 8 hours/shift. To be able to properly observe the change in the equipment reliabilities and line behavior, instead of using replications, a single run has been used. The main benefit from doing so is that it avoids any simulation interruption due to replication length and also enables the user to define the simulation as a single process as it would be in the real packaging line, rather than replication. Once the simulation run is completed and the results are obtained, Arena provides a report (Run Overview Report) that enables the user to see how the line performance, line utilization, input/output ratio along with the reliability and cost have changed.

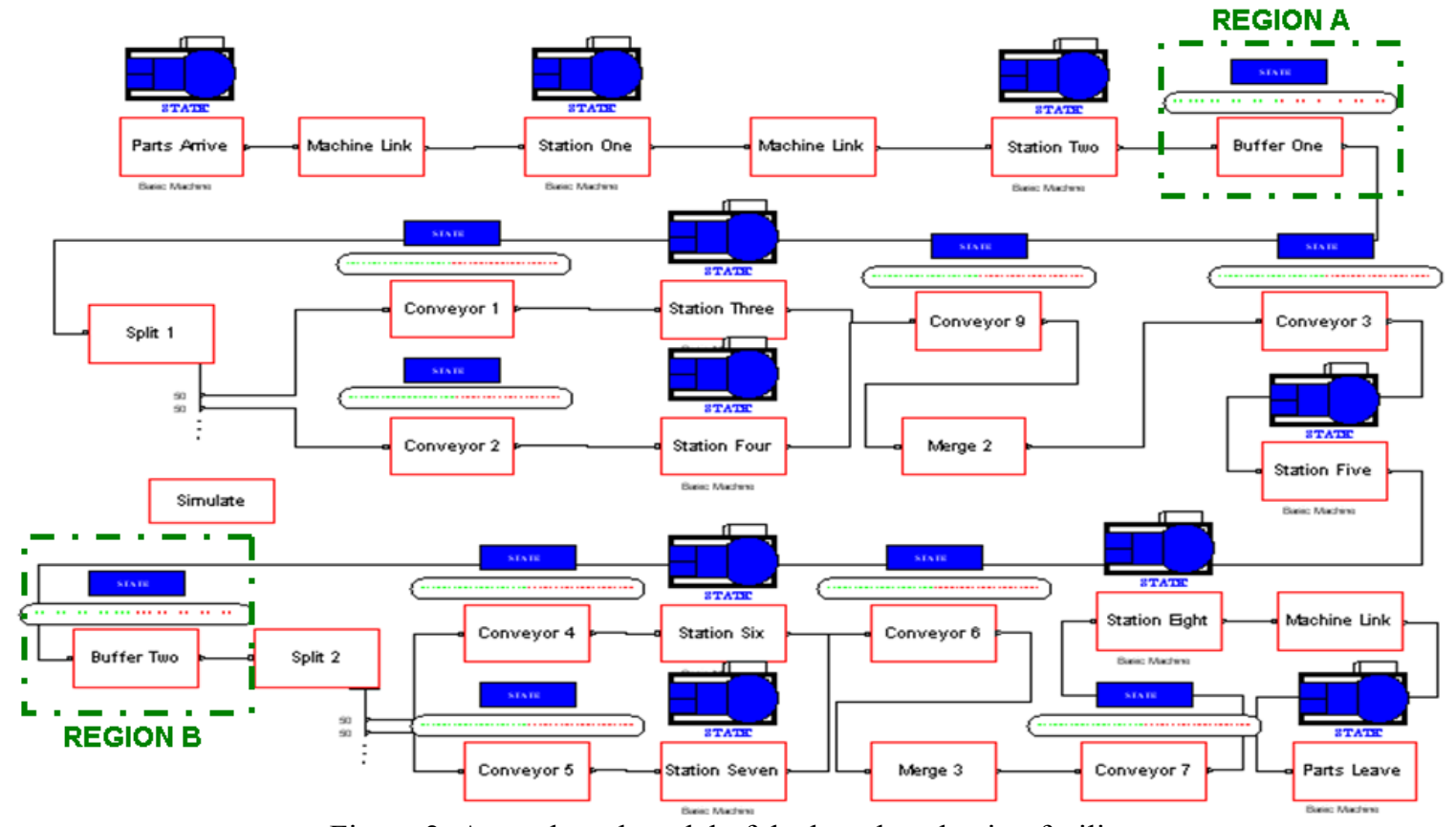

Figure 2: Arena-based model of the bread packaging facility 


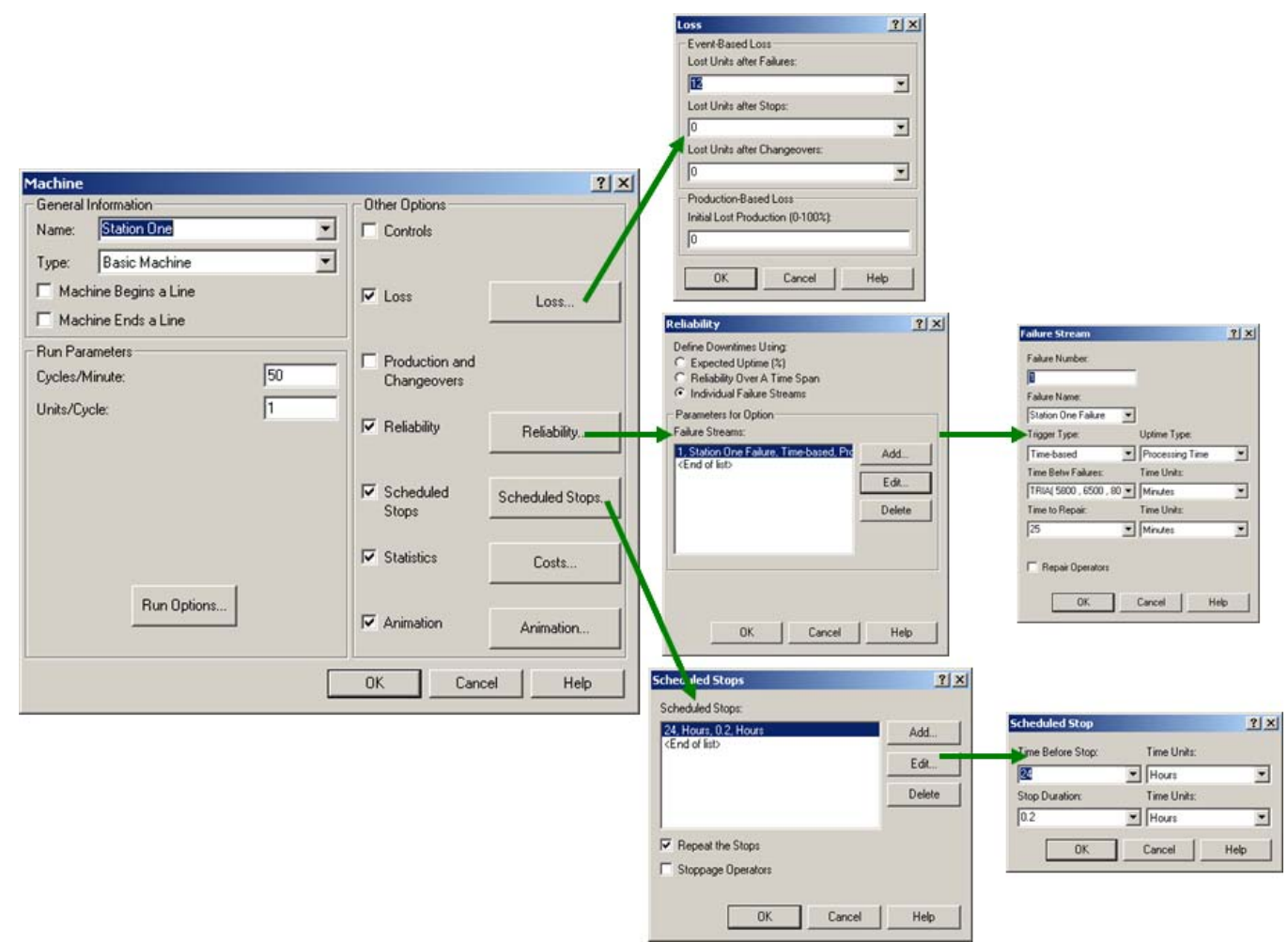

Figure 3: Building the station modules in Arena

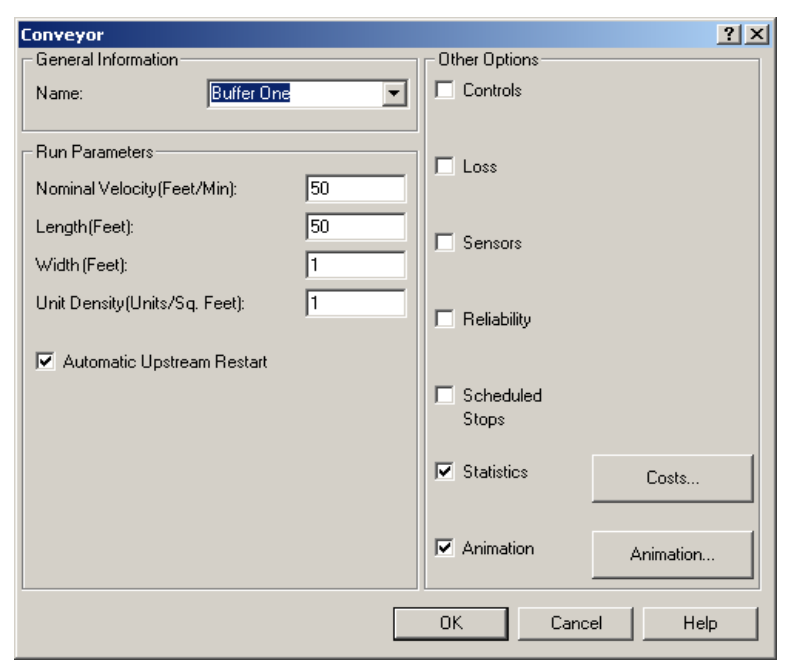

Figure 4: Building the Buffer Using a Conveyor Module

Data Generation: Recalling that the operating principle of GMO is to stop the packaging line all at once for a certain period of time and perform preventive maintenance, the imposed constraint for this example is that no station should fall below the $85 \%, 90 \%$ and $95 \%$ reliability levels, for the three consecutive scenarios that were conducted. The line's stoppage times for each reliability level is different and shown in Table 1. The maintenance schedule row of Table 1 indicates that Station 4 is the first station to reach the imposed reliability constraints, therefore all the other stations follow the time pattern and go under PM when station 4 reaches $85 \%, 90 \%$ and $95 \%$ reliability levels at $5^{\text {th }}, 10^{\text {th }}$, and $16^{\text {th }}$ hours respectively. 
Altuger and Chassapis

Table 1: System and run parameters of the GMO for the Arena model

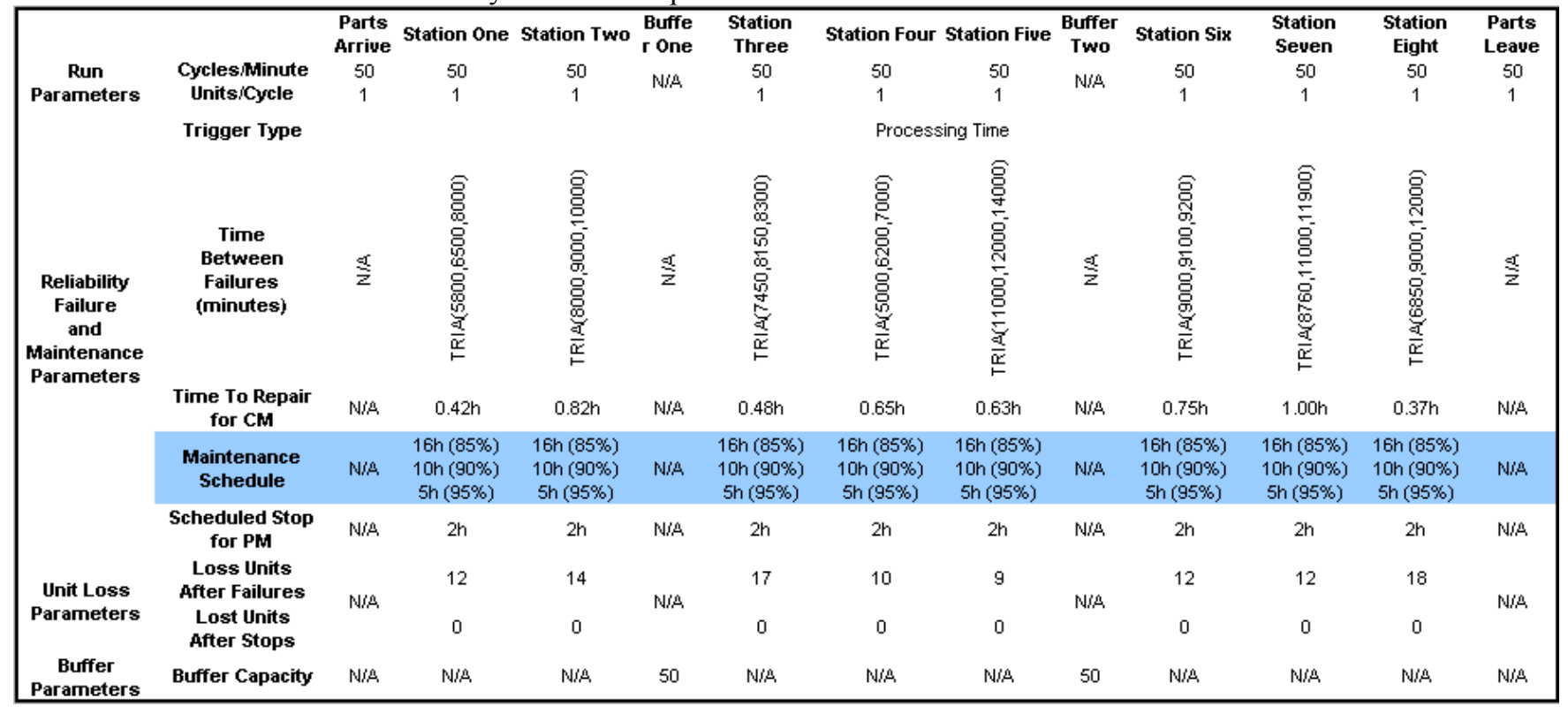

Under the RMO preventive maintenance scheme every time a station's reliability hits the $85 \%, 90 \%$ and $95 \%$ mark for the three scenarios under consideration, the station will be stopped and a preventive maintenance will be performed. Once the preventive maintenance for that station is completed, the station will resume operation with a $100 \%$ reliability. The maintenance row of Table 2 provides a listing of when each station reaches the constraint reliability level, and how long it will be stopped for PM.

Table 2: System and run parameters of the RMO for the Arena model

\begin{tabular}{|c|c|c|c|c|c|c|c|c|c|c|c|c|c|}
\hline \multirow{3}{*}{$\begin{array}{c}\text { Run } \\
\text { Parameters }\end{array}$} & & $\begin{array}{l}\text { Parts } \\
\text { Arrive }\end{array}$ & Station One & Station Two & $\begin{array}{l}\text { Buffe } \\
\text { r One }\end{array}$ & $\begin{array}{l}\text { Station } \\
\text { Three }\end{array}$ & Station Four & Station Five & $\begin{array}{l}\text { Buffer } \\
\text { Two }\end{array}$ & Station Six & $\begin{array}{l}\text { Station } \\
\text { Seven }\end{array}$ & $\begin{array}{l}\text { Station } \\
\text { Eight }\end{array}$ & $\begin{array}{l}\text { Parts } \\
\text { Leave }\end{array}$ \\
\hline & $\begin{array}{l}\text { Cycles/Minute } \\
\text { Units/Cycle }\end{array}$ & $\begin{array}{c}50 \\
1\end{array}$ & $\begin{array}{c}50 \\
1\end{array}$ & 50 & \multirow[t]{2}{*}{$N / A$} & $\begin{array}{c}50 \\
1\end{array}$ & 50 & $\begin{array}{c}50 \\
1\end{array}$ & \multirow[t]{2}{*}{ N/A } & 50 & $\begin{array}{c}50 \\
1\end{array}$ & $\begin{array}{c}50 \\
1\end{array}$ & $\begin{array}{c}50 \\
1\end{array}$ \\
\hline & Trigger Type & \multicolumn{10}{|c|}{ Processing Time } & & \\
\hline \multirow[t]{4}{*}{$\begin{array}{l}\text { Reliability } \\
\text { Failure } \\
\text { and } \\
\text { Maintenance } \\
\text { Parameters }\end{array}$} & $\begin{array}{c}\text { Time } \\
\text { Between } \\
\text { Failures } \\
\text { (minutes) }\end{array}$ & $\stackrel{\cong}{2}$ & 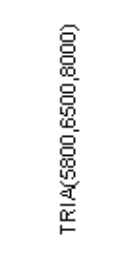 & 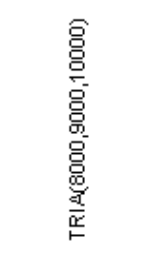 & $\stackrel{a}{z}$ & 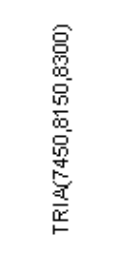 & 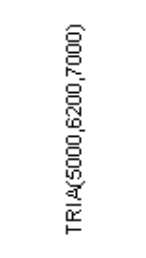 & 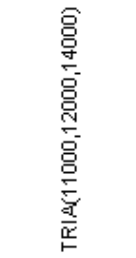 & $\frac{1}{z}$ & 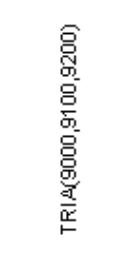 & 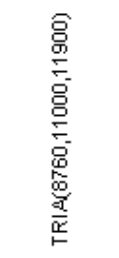 & 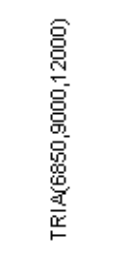 & $\frac{\mathfrak{z}}{2}$ \\
\hline & $\begin{array}{l}\text { Time To Repair } \\
\text { for CM }\end{array}$ & N/A & $0.42 \mathrm{~h}$ & $0.82 \mathrm{~h}$ & N/A & $0.48 \mathrm{~h}$ & $0.65 \mathrm{~h}$ & $0.63 \mathrm{~h}$ & $\mathrm{~N} / \mathrm{A}$ & $0.75 \mathrm{~h}$ & $1.00 \mathrm{~h}$ & $0.37 \mathrm{~h}$ & N/A \\
\hline & $\begin{array}{l}\text { Maintenance } \\
\text { Schedule }\end{array}$ & N/A & $\begin{array}{c}17 \mathrm{~h}(85 \%) \\
11 \mathrm{~h}(90 \%) \\
5 \mathrm{~h}(95 \%)\end{array}$ & $\begin{array}{c}24 h(85 \%) \\
15 h(90 \%) \\
\text { Th }(95 \%)\end{array}$ & N/A & $\begin{array}{c}22 \mathrm{~h}(85 \%) \\
14 \mathrm{~h}(90 \%) \\
6 \mathrm{~h}(95 \%)\end{array}$ & $\begin{array}{c}16 \mathrm{~h}(85 \%) \\
10 \mathrm{~h}(90 \%) \\
5 \mathrm{~h}(95 \%)\end{array}$ & $\begin{array}{l}32 \mathrm{~h}(85 \%) \\
21 \mathrm{~h}(90 \%) \\
10 \mathrm{~h}(95 \%)\end{array}$ & N/A & $\begin{array}{c}24 h(85 \%) \\
15 h(90 \%) \\
7 h(95 \%)\end{array}$ & $\begin{array}{c}29 \mathrm{~h}(85 \%) \\
19 \mathrm{~h}(90 \%) \\
\operatorname{9h}(95 \%)\end{array}$ & $\begin{array}{c}24 \mathrm{~h}(85 \%) \\
15 \mathrm{~h}(90 \%) \\
\text { 7h }(95 \%)\end{array}$ & N/A \\
\hline & $\begin{array}{c}\text { Scheduled Stop } \\
\text { for PM }\end{array}$ & N/A & $0.2 \mathrm{~h}$ & $0.27 \mathrm{~h}$ & $\mathrm{~N} / \mathrm{A}$ & $0.16 \mathrm{~h}$ & $0.13 \mathrm{~h}$ & $0.24 \mathrm{~h}$ & N/A & $0.18 \mathrm{~h}$ & $0.22 \mathrm{~h}$ & $0.18 \mathrm{~h}$ & N/A \\
\hline \multirow{2}{*}{$\begin{array}{l}\text { Unit Loss } \\
\text { Parameters }\end{array}$} & $\begin{array}{l}\text { Loss Units } \\
\text { After Failures }\end{array}$ & N/A & 12 & 14 & \multirow{2}{*}{ N/A } & 17 & 10 & 9 & \multirow[t]{2}{*}{ N/A } & 12 & 12 & 18 & \multirow[t]{2}{*}{ N/A } \\
\hline & $\begin{array}{c}\text { Lost Units } \\
\text { After Stops }\end{array}$ & W & 0 & 0 & & 0 & 0 & 0 & & 0 & 0 & 0 & \\
\hline $\begin{array}{c}\text { Buffer } \\
\text { Parameters }\end{array}$ & Buffer Capacity & N/A & $\mathrm{N} / \mathrm{A}$ & N/A & 50 & $\mathrm{~N} / \mathrm{A}$ & N/A & N/A & 50 & N/A & $\mathrm{N} / \mathrm{A}$ & N/A & N/A \\
\hline
\end{tabular}

Recalling that in the VMO scheme the closer the part to the end of the line when it is damaged, the higher penalty value will be associated with that lost, preference to maintenance is given to stations that are closest to the end of the line as their reliability approaches the minimum acceptable level. Running the simulation without any PM schedule and applying Equation 4 on the results will provide an order in which the PM should be performed. For the bread packaging line at hand, the order of maintenance is calculated from first through last as: S8, S7, S5, S4, S2, S1, S6, and S3. Once the order of mainten- 


\section{Altuger and Chassapis}

ance is obtained then the VMO preventive maintenance schedule can be set as shown in Table 3, for all three reliability constraint scenarios $(85 \%, 90 \%, 95 \%)$.

Table 3: System and run parameters of the VMO for the Arena model

\begin{tabular}{|c|c|c|c|c|c|c|c|c|c|c|c|c|c|}
\hline \multirow[b]{2}{*}{$\begin{array}{c}\text { Run } \\
\text { Parameters }\end{array}$} & & $\begin{array}{c}\text { Parts } \\
\text { Arrive }\end{array}$ & Station One & Station Two & $\begin{array}{l}\text { Buffe } \\
\text { r One }\end{array}$ & $\begin{array}{l}\text { Station } \\
\text { Three }\end{array}$ & Station Four & Station Five & $\begin{array}{l}\text { Buffer } \\
\text { Two }\end{array}$ & Station Six & $\begin{array}{l}\text { Station } \\
\text { Seven }\end{array}$ & $\begin{array}{c}\text { Station } \\
\text { Eight }\end{array}$ & $\begin{array}{l}\text { Parts } \\
\text { Leave }\end{array}$ \\
\hline & $\begin{array}{l}\text { Cycles/Minute } \\
\text { Units/Cycle }\end{array}$ & $\begin{array}{c}50 \\
1\end{array}$ & $\begin{array}{c}50 \\
1\end{array}$ & $\begin{array}{c}50 \\
1\end{array}$ & N/A & $\begin{array}{c}50 \\
1\end{array}$ & $\begin{array}{c}50 \\
1\end{array}$ & $\begin{array}{c}50 \\
1\end{array}$ & N/A & $\begin{array}{c}50 \\
1\end{array}$ & $\begin{array}{c}50 \\
1\end{array}$ & $\begin{array}{c}50 \\
1\end{array}$ & $\begin{array}{c}50 \\
1\end{array}$ \\
\hline \multirow{4}{*}{$\begin{array}{l}\text { Reliability } \\
\text { Failure } \\
\text { and } \\
\text { Maintenance } \\
\text { Parameters }\end{array}$} & Trigger Type & \multicolumn{12}{|c|}{ Processing Time } \\
\hline & $\begin{array}{c}\text { Time } \\
\text { Between } \\
\text { Failures } \\
\text { (minutes) }\end{array}$ & $\frac{5}{2}$ & 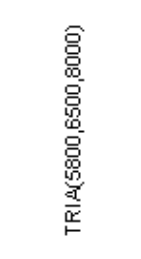 & 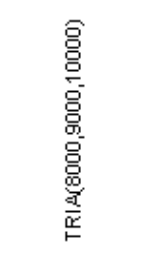 & $\stackrel{x}{2}$ & 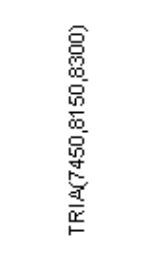 & 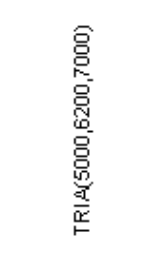 & 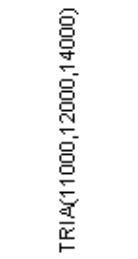 & $\frac{\pi}{2}$ & 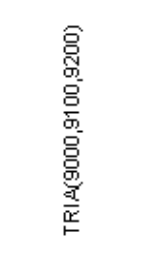 & 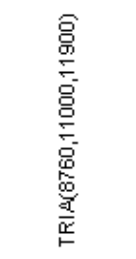 & 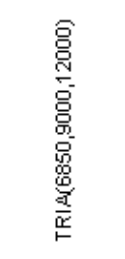 & $\frac{n}{2}$ \\
\hline & $\begin{array}{l}\text { Time To Repair } \\
\text { for } \mathrm{CM}\end{array}$ & N/A & $0.42 \mathrm{~h}$ & $0.82 \mathrm{~h}$ & N/A & $0.48 \mathrm{~h}$ & $0.65 \mathrm{~h}$ & $0.63 \mathrm{~h}$ & N/A & $0.75 \mathrm{~h}$ & $1.00 \mathrm{~h}$ & $0.37 \mathrm{~h}$ & NiA \\
\hline & $\begin{array}{l}\text { Maintenance } \\
\text { Schedule }\end{array}$ & N/A & $\begin{array}{c}25.04 \mathrm{~h}(85 \%) \\
16.04 \mathrm{~h}(90 \%) \\
8.04 \mathrm{~h}(95 \%)\end{array}$ & $\begin{array}{l}24.77 \mathrm{~h}(85 \%) \\
15.77 \mathrm{~h}(90 \%) \\
7.77 \mathrm{~h}(95 \%)\end{array}$ & N/A & $\begin{array}{c}25.42 \mathrm{~h}(85 \%) \\
16.42 \mathrm{~h}(90 \%) \\
8.42 \mathrm{~h}(95 \%)\end{array}$ & $\begin{array}{l}24.64 \mathrm{~h}(85 \%) \\
15.64 \mathrm{~h}(90 \%) \\
7.64 \mathrm{~h}(95 \%)\end{array}$ & $\begin{array}{c}24.4 \mathrm{~h}(85 \%) \\
15.4 \mathrm{~h}(90 \%) \\
7.4 \mathrm{~h}(95 \%)\end{array}$ & N/A & $\begin{array}{c}25.24 \mathrm{~h}(85 \%) \\
16.27 \mathrm{~h}(90 \%) \\
8.24 \mathrm{~h}(95 \%)\end{array}$ & $\begin{array}{c}24.18 \mathrm{~h}(85 \%) \\
15.18 \mathrm{~h}(90 \%) \\
7.18 \mathrm{~h}(95 \%)\end{array}$ & $\begin{array}{c}24 h(85 \%) \\
15 h(90 \%) \\
7 h(95 \%)\end{array}$ & N/A \\
\hline \multirow{3}{*}{$\begin{array}{l}\text { Unit Loss } \\
\text { Parameters }\end{array}$} & $\begin{array}{l}\text { Scheduled Stop } \\
\text { for PM }\end{array}$ & N/A & $0.2 \mathrm{~h}$ & $0.27 \mathrm{~h}$ & N/A & $0.16 \mathrm{~h}$ & $0.13 \mathrm{~h}$ & $0.24 \mathrm{~h}$ & N/A & $0.18 \mathrm{~h}$ & $0.22 \mathrm{~h}$ & $0.18 \mathrm{~h}$ & N/A \\
\hline & $\begin{array}{l}\text { Loss Units } \\
\text { After Failures }\end{array}$ & N/A & 12 & 14 & \multirow[t]{2}{*}{ N/A } & 17 & 10 & 9 & \multirow[t]{2}{*}{ N/A } & 12 & 12 & 18 & \multirow[t]{2}{*}{ N/A } \\
\hline & $\begin{array}{l}\text { Lost Units } \\
\text { After Stops }\end{array}$ & & 0 & 0 & & 0 & 0 & 0 & & 0 & 0 & 0 & \\
\hline $\begin{array}{c}\text { Buffer } \\
\text { Parameters }\end{array}$ & Buffer Capacity & N/A & N/A & N/A & 50 & N/A & N/A & N/A & 50 & N/A & N/A & N/A & N/A \\
\hline
\end{tabular}

Once the input tables are built for all three scenarios $(85 \%, 90 \%$ and $95 \%)$ for the three preventive maintenance schedule orders under consideration simulations can be run. Simulation results will be examined under several comparison criteria. For this case study, Table 4 lists the calculation and formulation for the four major criteria namely: performance (performance index, average output factor, and average output rate), usage (utilization), time (total time blocked and total time starved) and cost (equipment operating cost, cost of good product, and cost of lost product) that will be used to determine the most appropriate preventive maintenance scheduling scheme.

Table 4: Evaluation Criteria for the Three Scenarios $(85 \%, 90 \%, 95 \%)$ under consideration

\begin{tabular}{|c|c|}
\hline $\begin{array}{l}\text { Performance Index } \\
\text { (PI) }\end{array}$ & $P I=\frac{(\text { Yield }) *(\text { Utilization }) *(\text { Average_Output_Factor })}{100}$ \\
\hline $\begin{array}{l}\text { Average Output Factor } \\
\text { (AOF) }\end{array}$ & $\begin{array}{c}\text { The ratio of the Average Output Rate greater than zero statistic to the nominal run speed } \\
\text { of the machine }\end{array}$ \\
\hline $\begin{array}{l}\text { Average Output Rate } \\
\text { (AOR) }\end{array}$ & The average output rate of the machine when the output rate was greater than zero \\
\hline $\begin{array}{l}\text { Utilization } \\
(\mathbf{U})\end{array}$ & Utilization $=\frac{(\text { Total_Time_Output_Rate_Greater_Than_0 })}{(\text { Simulation_Run_Length }- \text { Total_Time_Stopped })}$ \\
\hline $\begin{array}{l}\text { Total Time Blocked } \\
\text { (TTB) }\end{array}$ & The total time the machine was in the Blocked state \\
\hline $\begin{array}{l}\text { Total Time Starved } \\
\text { (TTS) }\end{array}$ & The total time the machine was in the Fast, Working, or Slow state but was starved \\
\hline $\begin{array}{l}\text { Equipment Operating Cost } \\
\text { (EOC) }\end{array}$ & EOC $=(($ Simulation_Run_Length $)-($ Total_Time_Stopped $)) *($ Cost $/$ Hour $)$ \\
\hline $\begin{array}{l}\text { Cost of Good Product } \\
\text { (CGP) }\end{array}$ & $C G P=($ Total_Good_Units_Produced $) *($ Cost $/$ Good_Unit $)$ \\
\hline $\begin{array}{l}\text { Cost of Lost Product } \\
\text { (CLP) }\end{array}$ & $C L P=($ Total_Units_Lost $) *($ Cost $/$ Lost_Unit $)$ \\
\hline
\end{tabular}




\section{Altuger and Chassapis}

\subsection{Simulation Results}

Once the simulation runs are completed, the overall line behavior can be monitored through the output values (evaluation criteria) and overall line reliability which can be calculated using Equation 3. The simulation outcomes of the three scenarios are collected in four different evaluation criteria categories as: performance (performance index, average output factor and average output rate), usage (utilization), time (total time blocked and total time starved) and cost (equipment operating cost, cost of good product and cost of lost product). Sample criteria outcomes from each category are provided in Tables 5, 6, 7, and 8 as an example to demonstrate the data collection from simulation outputs. Table 5 provides the outcomes for the Performance Index (PI) criterion, which measures and evaluates system performance, Table 6 provides the outcomes for the Utilization $(\mathrm{U})$ value for every station, which denotes system efficiency. Table 7 provides the outcomes for Total Time Blocked (TTB), which measures the down times for each station, and Table 8 provides Cost of Good Product (CGP), showing the financial value of the good units produced during the simulation period. The remainder of the criteria are examined in the same fashion, and included in the calculations. A total of nine simulation runs have been performed for three different scenarios $(85 \%, 90 \%$ and $95 \%$ reliability constraints) for three preventive maintenance techniques.

Table 5: Simulation outcomes for GMO (85\%, 90\%, 95\%), RMO (85\%, 90\%, 95\%) and VMO ( $85 \%, 90 \%, 95 \%)$ - PI

\begin{tabular}{|c|c|c|c|c|c|c|c|c|c|c|c|c|c|c|}
\hline \multirow{5}{*}{$\begin{array}{c}\text { Evaluation } \\
\text { Criteria }\end{array}$} & Station Name & GMO - $85 \%$ & RMO - 85\% & VMO - 85\% & \multirow{2}{*}{$\begin{array}{l}\text { Evaluation } \\
\text { Criteria }\end{array}$} & Station Name & GMO - 90\% & RMO - 90\% & VMO - $90 \%$ & \multirow{2}{*}{$\begin{array}{c}\text { Evaluation } \\
\text { Criteria }\end{array}$} & \multirow{2}{*}{$\begin{array}{c}\text { Station Name } \\
\text { Parts Arrive }\end{array}$} & \multirow{2}{*}{ GMO - 95\% } & \multirow{2}{*}{ RMO - 95\% } & VMO - $95 \%$ \\
\hline & Parts Arrive & 44.5831 & 92.4812 & 92.7562 & & Parts Arrive & 20.4365 & 89.7223 & 90.1118 & & & & & 82.8470 \\
\hline & & 1151 & 93.5847 & 32 & & Station On & 24.5076 & 91.3535 & & & Station One & & 84.8735 & \\
\hline & Station Two & 50.1136 & 93.5143 & 93.7590 & & Station Two & 24.507 & 91.3 & & & 0 & 8.5773 & & 857107 \\
\hline & Station Three & 1.7505 & 0.4115 & 0.3158 & & Station Three & 1.7571 & 0.2699 & 0.1986 & & Station Three & 1.7742 & 0.1235 & 0.0944 \\
\hline Performance & Station Four & 48.1758 & 92.8084 & 92.9188 & Performance & Station Four & 22.4127 & 90.6101 & 90.65 & Performance & Stat & 6.1 & 83.6129 & 84.1495 \\
\hline Index (PI) & Station Five & 48.1984 & 92.7525 & 93.3337 & Index (PI) & Station Five & 22.4305 & 90.4700 & 91.3007 & Index (PI) & Station $\mathrm{Fi}$ & & 83.4450 & 85.4172 \\
\hline & Station Six & 0.8804 & 0.4116 & 0.1559 & & Station Six & 0.8842 & 0.4350 & 0.0973 & & Station Six & 0.8942 & 0.1114 & 0.0450 \\
\hline & Station Seven & 47.2093 & 92.3402 & 93.1069 & & Station Seven & 21.3742 & 90.0397 & 91.1009 & & Station Seven & 4.9199 & 83.3660 & 85.2229 \\
\hline & Station Eight & 47.2073 & 92.3286 & 92.9542 & & Station Eight & 21.3848 & 90.0749 & 90.8717 & & Station Eight & 4.9189 & 83.4665 & 84.8137 \\
\hline & Parts Leave & 41.9702 & 91.6447 & 92.2658 & & Parts Leave & 17.8219 & 89.0107 & 89.7983 & & Parts Leave & 3.515 & 81.3772 & 82.6907 \\
\hline
\end{tabular}

Table 6: Simulation outcomes for GMO (85\%, 90\%, 95\%), RMO (85\%, 90\%, 95\%) and VMO $(85 \%, 90 \%, 95 \%)-\mathrm{U}$

\begin{tabular}{|c|c|c|c|c|c|c|c|c|c|c|c|c|c|c|}
\hline $\begin{array}{c}\text { Evaluation } \\
\text { Criteria }\end{array}$ & Station Name & GMO - $85 \%$ & RMO - 85\% & VMO - $85 \%$ & $\begin{array}{c}\text { Evaluation } \\
\text { Criteria }\end{array}$ & Station Name & GMO - $90 \%$ & RMO - 90\% & VMO - $90 \%$ & $\begin{array}{c}\text { Evaluation } \\
\text { Criteria }\end{array}$ & Station Name & GMO - $95 \%$ & RMO - 95\% & VMO - $95 \%$ \\
\hline \multirow{9}{*}{ Utilization (U) } & $\begin{array}{l}\text { Parts Arrive } \\
\text { Station One }\end{array}$ & $\begin{array}{l}44.5831 \\
501119\end{array}$ & $\begin{array}{l}92.4812 \\
93.5680\end{array}$ & $\begin{array}{l}92.7562 \\
93.4964\end{array}$ & \multirow{9}{*}{ Utilization (U) } & $\begin{array}{l}\text { Parts Arrive } \\
\text { Station One }\end{array}$ & $\begin{array}{l}20.4365 \\
24.5055\end{array}$ & $\begin{array}{l}89.7293 \\
91.3566\end{array}$ & 90.1118 & \multirow{9}{*}{ Utilization (U) } & Parts Arrive & 6.1340 & 81.6272 & 82.8470 \\
\hline & $\begin{array}{l}\text { Station One } \\
\text { Station Two }\end{array}$ & $\begin{array}{l}50.11169 \\
501156\end{array}$ & $\begin{array}{l}93.5680 \\
93.5178\end{array}$ & $\begin{array}{l}93.4964 \\
937627\end{array}$ & & $\begin{array}{l}\text { Station One } \\
\text { Station Two }\end{array}$ & $\begin{array}{l}24.5085 \\
24.578\end{array}$ & $\begin{array}{l}91.3566 \\
91.392\end{array}$ & $\begin{array}{l}91.2332 \\
91.6498\end{array}$ & & $\begin{array}{l}\text { Station One } \\
\text { Station Two }\end{array}$ & $\begin{array}{l}8.5778 \\
85776\end{array}$ & $\begin{array}{l}84.8763 \\
847662\end{array}$ & $\begin{array}{l}84.8987 \\
857138\end{array}$ \\
\hline & Station Three & 3.4842 & 0.8196 & $\begin{array}{l}93.7627 \\
0.6316\end{array}$ & & Station Three & 3.4973 & 0.5331 & 0.3972 & & Station Three & 3.5314 & 0.2466 & 0.1889 \\
\hline & Station Four & 50.1194 & 93.2237 & 93.2401 & & Station Four & 24.4863 & 90.8804 & 90.8540 & & Station Four & 8.5572 & 83.7425 & 84.2485 \\
\hline & Station Five & 50.1372 & 93.1641 & 93.6530 & & Station Five & 24.4981 & 90.7366 & 91.5028 & & Station Five & 8.5718 & 83.5712 & 85.5149 \\
\hline & Station Six & 3.4826 & 1.2255 & 0.6238 & & Station Six & 3.4918 & 1.1199 & 0.3894 & & Station Six & 3.5157 & 0.3400 & 0.1811 \\
\hline & Station Seven & 50.1283 & 93.1631 & 93.5818 & & Station Seven & 24.4858 & 90.7371 & 91.3999 & & Station Seven & 8.5504 & 83.6030 & 85.3651 \\
\hline & Station Eight & 50.1261 & 93.1532 & 93.4300 & & Station Eight & 24.4969 & 90.7725 & 91.1711 & & Station Eight & 8.5461 & 83.7052 & 84.9568 \\
\hline & Parts Leave & 44.5637 & 92.4597 & 92.7345 & & Parts Leave & 20.4149 & 89.6968 & 90.0911 & & Parts Leave & 6.1068 & 81.6069 & 82.8272 \\
\hline
\end{tabular}

Table 7: Simulation outcomes for GMO (85\%, 90\%, 95\%), RMO (85\%, 90\%, 95\%) and VMO (85\%, 90\%, 95\%) - TTB

\begin{tabular}{|c|c|c|c|c|c|c|c|c|c|c|c|c|c|c|}
\hline \multirow{5}{*}{$\begin{array}{c}\text { Evaluation } \\
\text { Criteria }\end{array}$} & Station Name & GMO - 85\% & RMO - 85\% & VMO - 85\% & \multirow{2}{*}{$\begin{array}{c}\text { Evaluation } \\
\text { Criteria }\end{array}$} & Station Name & GMO - $90 \%$ & RMO - 90\% & VMO - $90 \%$ & \multirow{2}{*}{$\begin{array}{c}\text { Evaluation } \\
\text { Criteria }\end{array}$} & \multirow{2}{*}{$\begin{array}{l}\text { Station Name } \\
\text { Parts Arrive }\end{array}$} & GMO - $95 \%$ & \multirow{2}{*}{ RMO - 95\% } & VMO - 95\% \\
\hline & Parts Arrive & 2128.01 & 288.72 & 278.16 & & Parts Arrive & 3055.24 & 394.39 & 379.71 & & & 3604.45 & & 658.68 \\
\hline & & 1697.76 & 231.20 & 234.84 & & Station One & 2414.32 & 313.49 & 320.01 & & Station One & 2509 . 2 & 547.26 & 554.62 \\
\hline & & 1286.76 & 170.18 & 74.89 & & Station Two & 1894.23 & 228.65 & 236.97 & & Station Two & & 38872 & 41021 \\
\hline & Station Three & 3689.84 & 3807.88 & 3815.73 & & Station Three & 3679.69 & 3818.88 & 3824.73 & & Station Three & 3653.30 & 382988 & 383273 \\
\hline & Station Four & 869.27 & 106.28 & 121.52 & Total Time & Station Four & 1372.13 & 14308 & 16866 & Total Time & Station Four & 462.20 & 24940 & 299.27 \\
\hline Blocked (TTB) & Station Five & 470.87 & 86.81 & 94.60 & Blocked (TतB) & Station Five & 918.77 & 119.10 & 129.93 & Blocked (TतB) & & & & $\begin{array}{l}299.27 \\
23689\end{array}$ \\
\hline & Station Six & 3690.09 & 3791.64 & 3815.98 & & Station Six & 3679.94 & 3794.46 & 3824.98 & & Station Six & 3653.55 & 3825.64 & $\begin{array}{r}23032.98 \\
3832\end{array}$ \\
\hline & Station Seven & 57.42 & 33.84 & 35.93 & & Station Seven & 447.74 & 51.09 & 50.47 & & Station Seven & 0.37 & 97.50 & 95.51 \\
\hline & Stati & 0.00 & 0.00 & 0.00 & & Station Eight & 0.00 & 0.00 & 0.00 & & Station Eight & 0.00 & 0.00 & 0.00 \\
\hline & Parts Leave & 0.00 & 0.00 & 0.00 & & Parts Leave & 0.00 & 0.00 & 0.00 & & Parts Leave & 0.00 & 0.00 & 0.00 \\
\hline
\end{tabular}

Table 8: Simulation outcomes for GMO (85\%, 90\%, 95\%), RMO (85\%, 90\%, 95\%)and VMO (85\%, 90\%, 95\%) - CGP

\begin{tabular}{|c|c|c|c|c|c|c|c|c|c|c|c|c|c|c|}
\hline \multirow{5}{*}{$\begin{array}{c}\text { Evaluation } \\
\text { Criteria }\end{array}$} & Station Name & GMO - 85\% & RMO - 85\% & VMO - 85\% & \multirow{5}{*}{$\begin{array}{l}\text { Evaluation } \\
\text { Criteria }\end{array}$} & Station Name & GMO - 90\% & RMO - 90\% & VMO - 90\% & \multirow{5}{*}{$\begin{array}{l}\text { Evaluation } \\
\text { Criteria }\end{array}$} & Station Name & GMO - 95\% & RMO - 95\% & VMO - 95\% \\
\hline & Parts Arrive & $\begin{array}{c}0 \\
03192\end{array}$ & 0 & 0 & & Parts Arrive & 0 & 0 & $\begin{array}{r}0 \\
41521\end{array}$ & & Parts Arrive & 0.00 & $\begin{array}{c}0 \\
376154\end{array}$ & $\begin{array}{c}0 \\
13432\end{array}$ \\
\hline & $\begin{array}{l}\text { Station One } \\
\text { Station }\end{array}$ & $\begin{array}{l}20543192 \\
30813958\end{array}$ & $\begin{array}{l}42613856 \\
63919020\end{array}$ & $\begin{array}{l}42740612 \\
65409070\end{array}$ & & $\begin{array}{l}\text { Station One } \\
\text { Station }\end{array}$ & 9416804 & 41345876 & 41522108 & & Station One & & 37612544 & 38174632 \\
\hline & tion Two & $\begin{array}{l}30813858 \\
1007326\end{array}$ & 63919020 & 64109070 & & $\begin{array}{l}\text { Station Two } \\
\text { Station Three }\end{array}$ & 14124864 & 62017050 & 62281398 & & Station Two & & 56417136 & 57260436 \\
\hline & Station Three & 1807326 & 426609 & 327420 & & Station Three & 1809405 & 279855 & 2059 & & on Three & & & 97920 \\
\hline \multirow{6}{*}{$\begin{array}{l}\text { Cost of Good } \\
\text { Product (CGP) }\end{array}$} & Station Four & 44411391 & 95448492 & 95832657 & Cost of Good & Station Four & 19376640 & 92742372 & 93212829 & Cost of Good & Station Four & 4544001 & 84494637 & 85790007 \\
\hline & Station Five & 54301302 & 116661809 & 117126328 & Product (CGP) & Station Five & 23701458 & 113353900 & 113924646 & Product (CGP) & Station Five & 5575086 & 103269804 & 104851417 \\
\hline & Station Six & 1818036 & 853488 & 323352 & & Station Six & 1821168 & 901944 & 201852 & & Station Six & 1829106 & 230976 & 93852 \\
\hline & Station Seven & 87033096 & 190039464 & 191329830 & & Station $\mathrm{S}$ & & & 186211890 & & & 7290162 & 168747786 & 171473652 \\
\hline & Station Eight & 116039328 & 253379376 & 255096456 & & Station Eight & 49274232 & 246097272 & 248274264 & & Station Eight & 9718200 & 224991744 & 228623280 \\
\hline & Parts Leave & 0 & 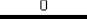 & & & Parts Leave & & & & & Parts Leave & 0 & 0 & 0 \\
\hline
\end{tabular}

As one proceeds with the PM selection process, it is crucial to examine the individual station reliabilities along with overall line reliability for each case. Figure 5 provides the reliability graphics for the " $85 \%$ station reliability" constraint simulation. When GMO preventive maintenance technique is applied, the line reliability level drops to the $64 \%$ mark just prior to maintenance. When RMO preventive maintenance technique is applied, the line reliability level fluctuates between $56 \%$ and $95 \%$, As expected, since the line is never stopped all together, the overall line reliability never reaches to $100 \%$ as it did in GMO. When VMO preventive maintenance technique is applied, the line reliability level changes between $54 \%$ and $98 \%$. 


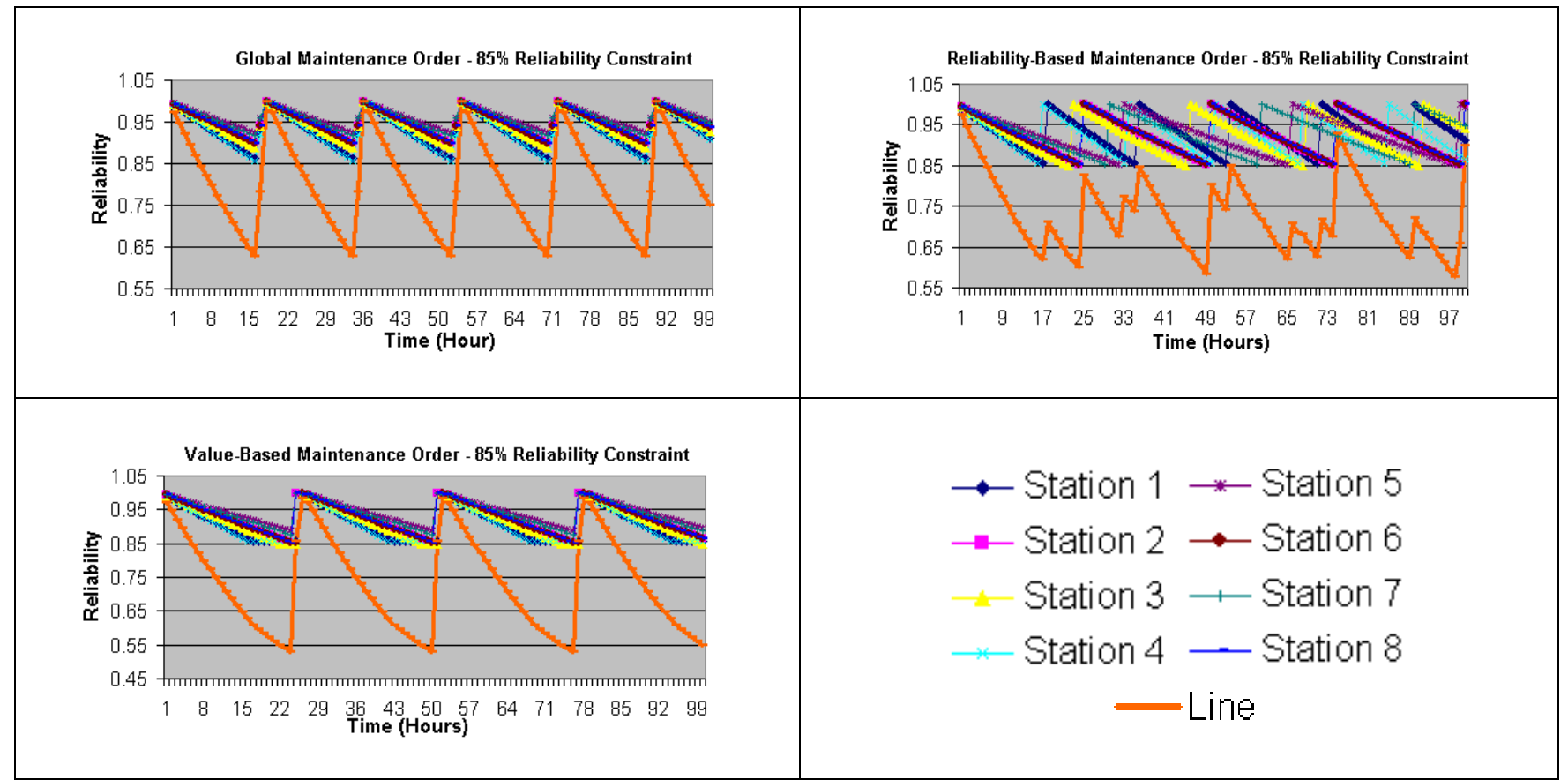

Figure 5: Machine and Line Reliability Results under GMO, RMO, and VMO for 85\% Station Reliability Constraint

Figure 6 provides the reliability graphics for the " $90 \%$ station reliability" constraint simulation. When GMO preventive maintenance technique is applied, the line reliability level is reduced to $75 \%$ just prior to maintenance. When RMO preventive maintenance technique is applied, the line reliability level fluctuates between $73 \%-97 \%$, not counting the starting point of $100 \%$. When VMO preventive maintenance technique is applied, the line reliability level changes between $69 \%-98 \%$.

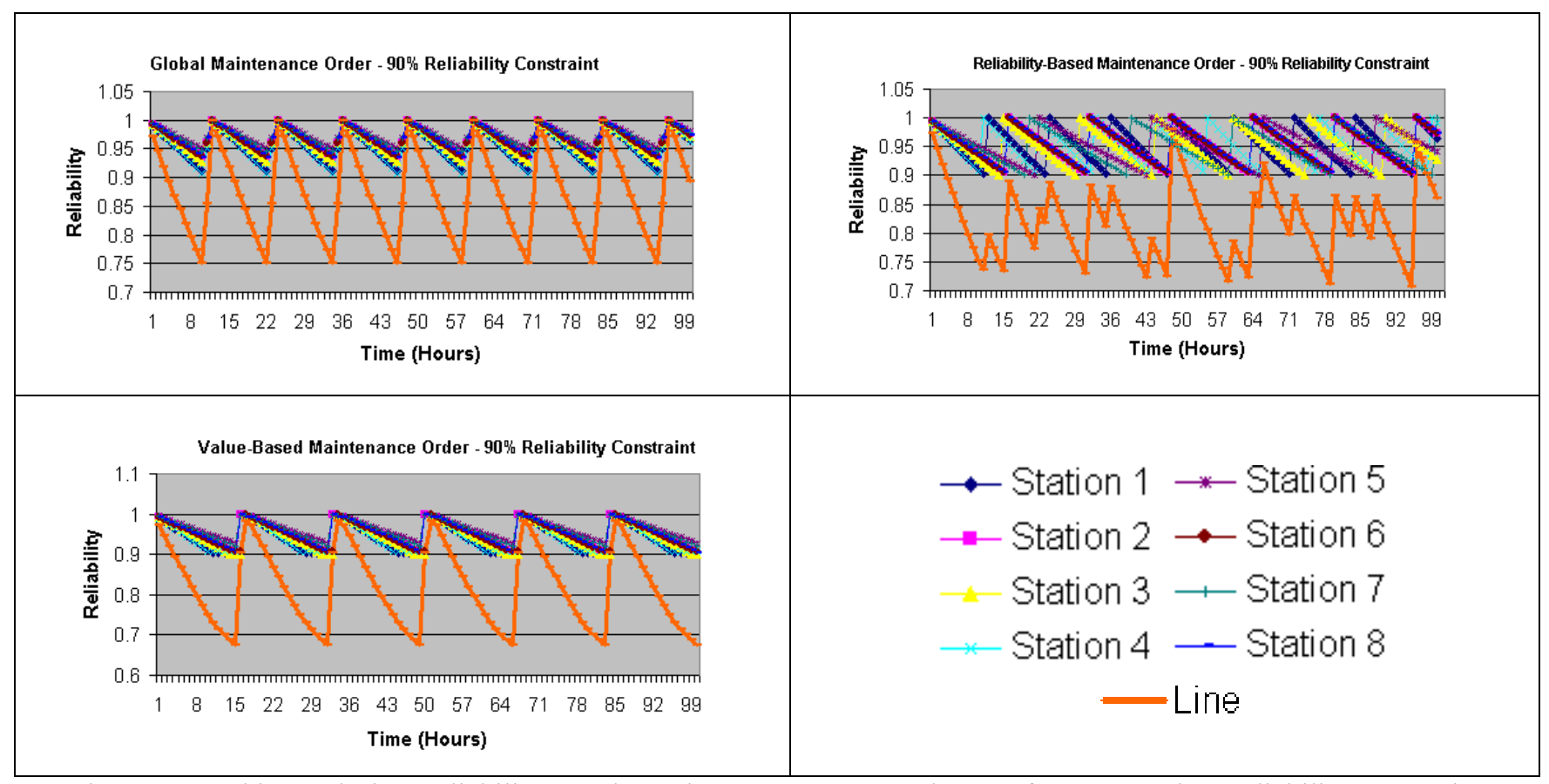

Figure 6: Machine and Line Reliability Results under GMO, RMO, and VMO for 90\% Station Reliability Constraint

Figure 7 provides the reliability graphics for the "95\% station reliability" constraint simulation. When GMO preventive maintenance technique is applied, the line reliability level changes between $100 \%$ and $87 \%$. When RMO preventive mainten- 


\section{Altuger and Chassapis}

ance technique is applied, the line reliability level fluctuates between $84 \%$ and $97 \%$, not counting the starting point of $100 \%$. When VMO preventive maintenance technique is applied, the line reliability level changes between $84 \%$ and $99 \%$.

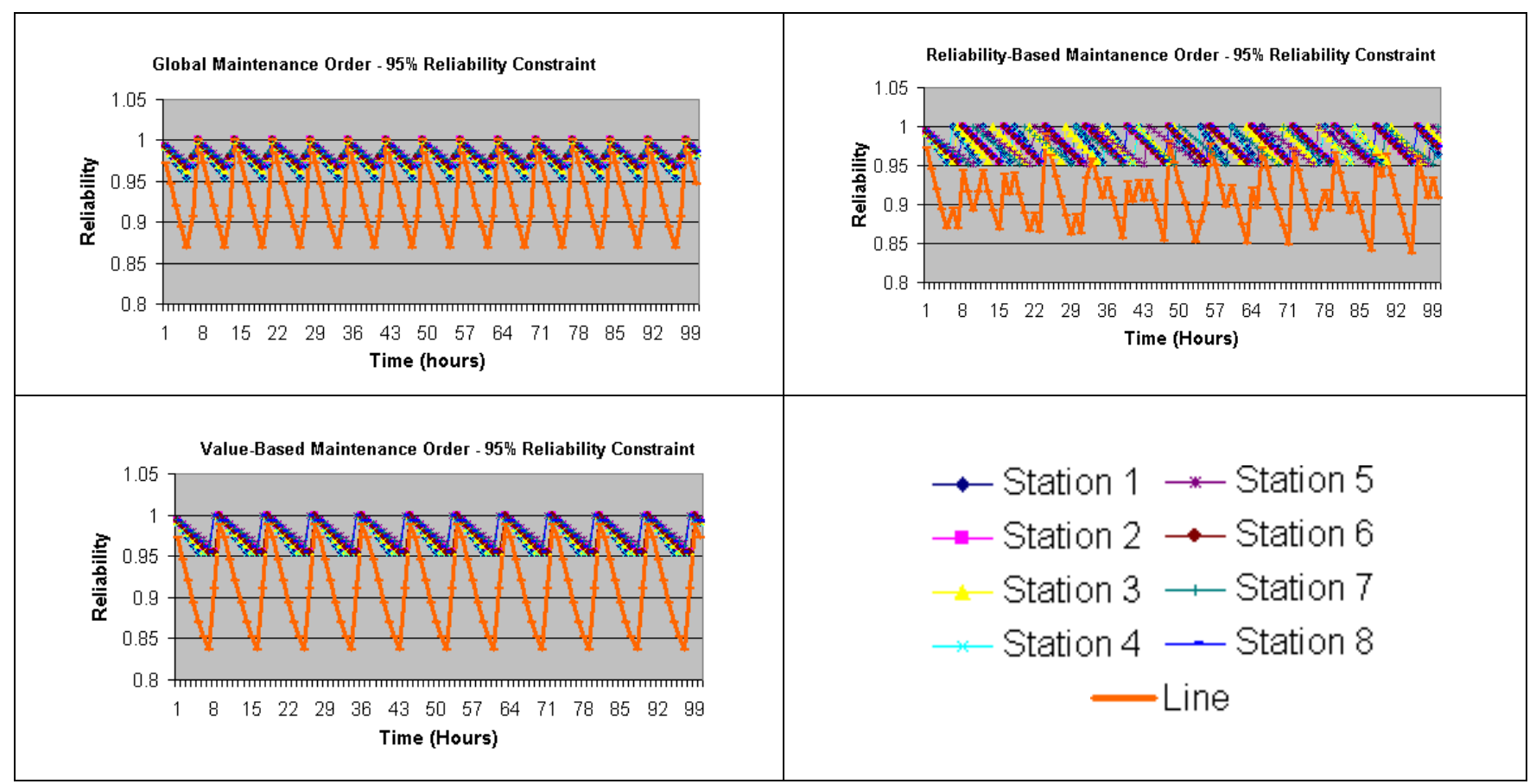

Figure 7: Machine and Line Reliability Results under GMO, RMO, and VMO for 95\% Station Reliability Constraint

Performing a selection in between the preventive maintenance techniques solely based on reliability does not provide any insights on the line's performance, utilization or line lead times and bottlenecks. Therefore it is always desirable to consider multiple evaluation criteria when deciding which preventive maintenance method should be used when setting up the PM schedule for a production line. A utility theory based approach (equation 5) will be used for the selection process: where $U_{i}$ denotes the utility of the $i^{\text {th }}$ item, $\mu_{i}$ denotes the weight value of the $i^{\text {th }}$ item, and $u_{i}$ denotes the numerical value of the $i^{\text {th }}$ item. The number of evaluation criteria and the extensiveness of said criteria is case specific and changes based on requirements and expectations from that line. The challenge here is to decide the relative importance of each criterion over the others. To overcome that challenge design engineers either define hierarchical rankings or employ rank assessment methods such as: rank sum, rank exponent, rank reciprocal, etc... to calculate weight values. Change in rankings or weight values may result in change in the outcome of the selection process. Once the weight assessment is completed, the preferences for each criterion should be defined. Preference indicates if higher or lower values of a certain criterion is preferred over the others. For the bread packaging case study: for performance index (PI), average output rate (AOR), average output factor (AOF), utilization (U) and cost of good product (CGP) higher values are preferred, where as for total time blocked (TTB), total time starved (TTS) and cost of lost product (CLP) lower values are preferred.

$$
U_{i}=\mu_{i}^{*} u_{i}
$$

To be able to accurately comment on the selection process, and to be able to see the effects of different hierarchical rankings and different weight values, in this case study four different hierarchical rankings along with different sets of weight values have been considered. These four rankings and their utility outputs are shown in Table 9 as A, B, C and D. Once the utility values for individual stations are obtained, than the overall line utilities can be calculated by simply summing up all stations' utility values. For all four cases (A, B, C, and D), and for all minimum reliability scenarios $(85 \%, 90 \%$, and $95 \%)$; it can be seen from Table 9 that, RMO provided the highest overall utility values, suggesting that for the case study at hand and for the scenarios considered using RMO to set up PM schedule will provide higher line performance, higher line utilization, as well as low starvation and blockage times, along with higher number of good products. 


\section{Altuger and Chassapis}

Table 9: MCDM Final Utility Values for GMO (85\%, 90\%, 95\%), RMO (85\%, 90\%, 95\%) and VMO (85\%, 90\%, 95\%)

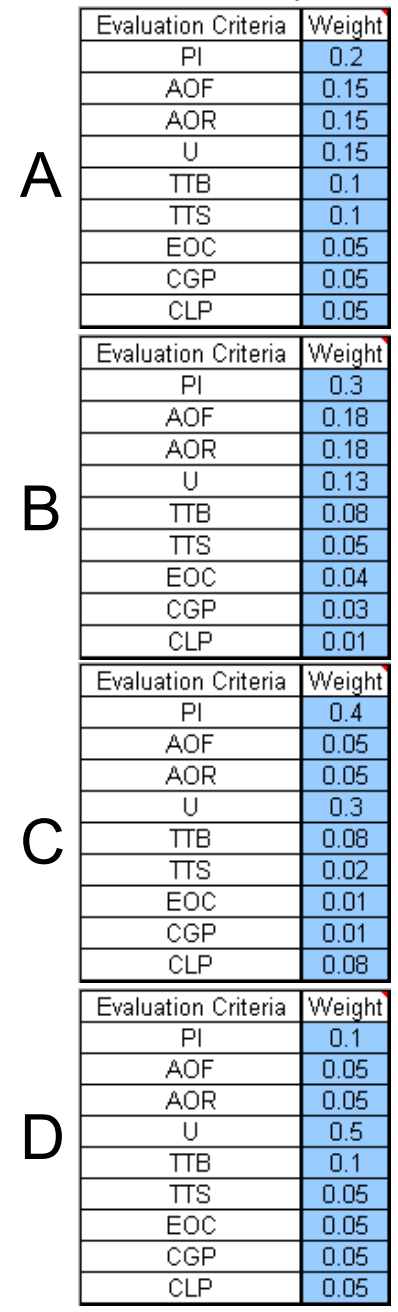

\begin{tabular}{|c|c|c|c|c|c|c|c|c|c|}
\hline \multirow{2}{*}{$\begin{array}{c}\text { Station } \\
\text { No }\end{array}$} & \multicolumn{3}{|c|}{$85 \%$} & \multicolumn{3}{|c|}{$90 \%$} & \multicolumn{3}{|c|}{ 95\% } \\
\hline & GMO & RMO & VMO & GMO & RMO & VMO & GMO & RMO & VMO \\
\hline 1 & 0.20 & 0.40 & 0.40 & 0.21 & 0.41 & 0.38 & 0.20 & 0.40 & 0.40 \\
\hline 2 & 0.16 & 0.42 & 0.42 & 0.16 & 0.42 & 0.42 & 0.16 & 0.42 & 0.42 \\
\hline 3 & 0.62 & 0.26 & 0.12 & 0.55 & 0.32 & 0.13 & 0.72 & 0.15 & 0.13 \\
\hline 4 & 0.03 & 0.48 & 0.49 & 0.02 & 0.49 & 0.49 & 0.03 & 0.49 & 0.48 \\
\hline 5 & 0.03 & 0.48 & 0.49 & 0.03 & 0.48 & 0.49 & 0.09 & 0.45 & 0.46 \\
\hline 6 & 0.48 & 0.40 & 0.12 & 0.48 & 0.40 & 0.12 & 0.50 & 0.36 & 0.14 \\
\hline 7 & 0.03 & 0.48 & 0.49 & 0.03 & 0.48 & 0.49 & 0.09 & 0.45 & 0.46 \\
\hline 8 & 0.08 & 0.45 & 0.47 & 0.07 & 0.46 & 0.47 & 0.08 & 0.46 & 0.46 \\
\hline SUM U & 1.63 & 3.37 & 3.00 & 1.55 & 3.46 & 2.99 & 1.87 & 3.18 & 2.95 \\
\hline
\end{tabular}

\begin{tabular}{|c|c|c|c|c|c|c|c|c|c|}
\hline \multirow{2}{*}{$\begin{array}{c}\text { Station } \\
\text { No }\end{array}$} & \multicolumn{3}{|c|}{$85 \%$} & \multicolumn{3}{|c|}{ 90\% } & \multicolumn{3}{|c|}{$95 \%$} \\
\hline & GMO & RMO & VhiO & GHO & RMO & VMIO & GMO & RMO & VMO \\
\hline 1 & 0.18 & 0.41 & 0.41 & 0.19 & 0.42 & 0.39 & 0.18 & 0.41 & 0.41 \\
\hline 2 & 0.16 & 0.42 & 0.42 & 0.16 & 0.42 & 0.42 & 0.16 & 0.42 & 0.42 \\
\hline 3 & 0.69 & 0.34 & 0.07 & 0.60 & 0.34 & 0.06 & 0.81 & 0.14 & 0.05 \\
\hline 4 & 0.01 & 0.49 & 0.50 & 0.01 & 0.49 & 0.50 & 0.01 & 0.50 & 0.49 \\
\hline 5 & 0.01 & 0.49 & 0.50 & 0.01 & 0.49 & 0.50 & 0.05 & 0.47 & 0.48 \\
\hline 6 & 0.49 & 0.46 & 0.05 & 0.49 & 0.46 & 0.05 & 0.54 & 0.40 & 0.06 \\
\hline 7 & 0.01 & 0.49 & 0.50 & 0.01 & 0.49 & 0.50 & 0.05 & 0.47 & 0.48 \\
\hline 8 & 0.05 & 0.47 & 0.48 & 0.05 & 0.47 & 0.48 & 0.05 & 0.47 & 0.48 \\
\hline SUM U & 1.60 & 3.57 & 2.93 & 1.52 & 3.58 & 2.90 & 1.85 & 3.28 & 2.87 \\
\hline
\end{tabular}

\begin{tabular}{|cccc|ccc|ccc|}
\hline $\begin{array}{c}\text { Station } \\
\text { No }\end{array}$ & GMO & $\begin{array}{c}\mathbf{8 5} \% \\
\text { RMO }\end{array}$ & VMO & GMO & $\begin{array}{c}\mathbf{9 0} \% \\
\text { RMO }\end{array}$ & VMO & GMO & $\begin{array}{c}\text { R5\% } \\
\text { RMO }\end{array}$ & VMO \\
$\mathbf{1}$ & 0.10 & 0.45 & 0.45 & 0.11 & 0.48 & 0.41 & 0.10 & 0.45 & 0.45 \\
$\mathbf{2}$ & 0.09 & 0.46 & 0.45 & 0.09 & 0.45 & 0.46 & 0.09 & 0.45 & 0.46 \\
$\mathbf{3}$ & 0.74 & 0.18 & 0.08 & 0.73 & 0.19 & 0.08 & 0.80 & 0.12 & 0.08 \\
$\mathbf{4}$ & 0.04 & 0.48 & 0.48 & 0.04 & 0.48 & 0.48 & 0.04 & 0.48 & 0.48 \\
$\mathbf{5}$ & 0.04 & 0.48 & 0.48 & 0.04 & 0.48 & 0.48 & 0.09 & 0.45 & 0.46 \\
$\mathbf{6}$ & 0.64 & 0.29 & 0.07 & 0.62 & 0.31 & 0.07 & 0.72 & 0.19 & 0.09 \\
$\mathbf{7}$ & 0.04 & 0.48 & 0.48 & 0.05 & 0.47 & 0.48 & 0.08 & 0.45 & 0.47 \\
$\mathbf{8}$ & 0.08 & 0.45 & 0.47 & 0.09 & 0.45 & 0.46 & 0.08 & 0.46 & 0.46 \\
\hline SUM U & $\mathbf{1 . 7 7}$ & $\mathbf{3 . 2 7}$ & $\mathbf{2 . 9 6}$ & $\mathbf{1 . 7 7}$ & $\mathbf{3 . 3 1}$ & $\mathbf{2 . 9 2}$ & $\mathbf{2 . 0 0}$ & $\mathbf{3 . 0 5}$ & $\mathbf{2 . 9 5}$ \\
\hline
\end{tabular}

\begin{tabular}{|c|c|c|c|c|c|c|c|c|c|}
\hline \multirow{2}{*}{$\begin{array}{c}\text { Station } \\
\text { No }\end{array}$} & \multicolumn{3}{|c|}{$85 \%$} & \multicolumn{3}{|c|}{$90 \%$} & \multicolumn{3}{|c|}{$95 \%$} \\
\hline & GMO & RMO & VMOO & GMO & RMO & VMO & GMO & RMO & VMAO \\
\hline 1 & 0.10 & 0.45 & 0.45 & 0.11 & 0.51 & 0.38 & 0.10 & 0.45 & 0.45 \\
\hline 2 & 0.08 & 0.46 & 0.46 & 0.08 & 0.46 & 0.46 & 0.07 & 0.46 & 0.47 \\
\hline 3 & 0.75 & 0.16 & 0.09 & 0.74 & 0.17 & 0.09 & 0.81 & 0.09 & 0.10 \\
\hline 4 & 0.02 & 0.49 & 0.49 & 0.02 & 0.49 & 0.49 & 0.03 & 0.49 & 0.48 \\
\hline 5 & 0.03 & 0.48 & 0.49 & 0.03 & 0.48 & 0.49 & 0.09 & 0.45 & 0.46 \\
\hline 6 & 0.66 & 0.26 & 0.08 & 0.65 & 0.28 & 0.07 & 0.73 & 0.18 & 0.09 \\
\hline 7 & 0.02 & 0.49 & 0.49 & 0.03 & 0.48 & 0.49 & 0.09 & 0.45 & 0.46 \\
\hline 8 & 0.08 & 0.45 & 0.47 & 0.08 & 0.46 & 0.46 & 0.08 & 0.46 & 0.46 \\
\hline SUM U & 1.74 & 3.24 & 3.02 & 1.74 & 3.33 & 2.93 & 2.00 & 3.03 & 2.97 \\
\hline
\end{tabular}

\section{CONCLUSIONS AND FUTURE WORK}

The objective of the study presented in this paper is to benefit from discrete event simulations to assess different preventive maintenance scheduling techniques (GMO, RMO and VMO), and to incorporate simulations as a decision-making support tool to the evaluation and decision process when selecting a preventive maintenance technique. A bread packaging line is examined as a case study, where the line behavior and outcomes are obtained by using an Arena-based simulation model. The case study involved three parts, where the minimum allowable reliability level for each station is set to $85 \%, 90 \%$ and $95 \%$ respectively. A multi criteria decision making approach based on utility theory is employed for the preventive maintenance technique selection process to select the PM schedule that gives the best utility, performance and reliability values Production line utilization, performance and reliability are very tightly connected to the preventive maintenance scheduling, making preventive maintenance scheduling a major point of interest. Implementing the right preventive maintenance schedule can be challenging considering that different production lines carry different parameters, specifications, layout and complexity. The method outlined in this paper aims to provide an overall roadmap on how to incorporate simulation tools and benefit form their outcomes in a multi criteria decision making problem.

\section{REFERENCES}

Adams, M., P. Componation, H. Czarnecki, and B. J. Schroer. 1999. Simulation as a Tool for Continuous Process Improvement. In Proceedings of the 1999 Winter Simulation Conference, ed P. A. Farrington, H. B. Nembhard, D. T. Sturrock, and G. W. Evans, 766-773. Piscataway, New Jersey: Institute of Electrical and Electronics Engineers, Inc. 


\section{Altuger and Chassapis}

Al-Aomar, R. 2000. Product-Mix Analysis with Discrete Event Simulation. In Proceedings of the 2000 Winter Simulation Conference, ed J. A. Jones, R. R. Barton, K. Kang, and P. A. Fishwick, 1385-1392. Piscataway, New Jersey: Institute of Electrical and Electronics Engineers, Inc.

Cassady, C. R., and E. Kutanoglu. 2003. Minimizing Job Tardiness Using Integrated Preventive Maintenance Planning and Production Scheduling, IIE Transactions, 2003, Vol. 35, 503-515

Cassady, C. R., and E. Kutanoglu. 2005. Integrating Preventive Maintenance Planning and Production Scheduling for a Single Machine. IEEE Transactions on Reliability, June 2005, Vol. 54, No.2, 304-309

Chong. C. S., A. I. Sivakumar, and R. Gay. 2003. Simulation-Based Scheduling for Dynamic Discrete Manufacturing. In Proceedings of the 2003 Winter Simulation Conference, ed. S. Chick, P. J. Sanchez, D. Ferrin, and D. J. Morrice, 14651473. Piscataway, New Jersey: Institute of Electrical and Electronics Engineers, Inc.

Dekker, R. 1996. Applications of Maintenance Optimization Models: A Review and Analysis, Reliability Engineering and System Safety Journal, 1996, Vol.51, 229-240

Harrell, C., and B. Gladwin. 2007. Productivity improvement in appliance manufacturing, In Proceedings of the 2007 Winter Simulation Conference, ed. S. G. Henderson, B. Biller, M.-H. Hsieh, J. Shortle, J. D. Tew and R. R. Barton, $1610-1614$. Piscataway, New Jersey: Institute of Electrical and Electronics Engineers, Inc.

Hickie, M., and J. W. Fowler. 1999. Ancillary Effect of Simulation, In Proceedings of the 1999 Winter Simulaiton Conference, ed. P. A. Farrington, H. B. Nembhard, D. T. Sturrock, and G. W. Evans, 754-758. Piscataway, New Jersey: Institute of Electrical and Electronics Engineers, Inc.

Johansson, B., and J. Kaiser. 2002. Turn Lost Production into Profit - Discrete Event Simulaiton Applied on Resetting Performance in Manufacturing Systems, In Proceedings of the 2002 Winter Simulation Conference, ed. E. Yucesan, C.-H. Chen, J. L. Snowdon, and J. M. Charnes, 1065-1072. Piscataway, New Jersey: Institute of Electrical and Electronics Engineers, Inc.

Kelton, D. W., R. P. Sadowski, and D. A. Sadowski. 2002. Simulation with Arena, Second Edition, McGraw-Hill, Inc.

Knoll, J. M., and Heim, J. A. 2000. Ensuring the Successful Adoption of Discrete Event Simulation in a Manufacturing Environment, In Proceedings of the 2000 Winter Simulation Conference, ed. J. A. Joines, R. R. Barton, K. Kang, and P. A. Fishwick, 1297-1304. Piscataway, New Jersey: Institute of Electrical and Electronics Engineers, Inc.

Mc Lean, C., and G. Shao. 2003. Generic Case Studies for Manufacturing Simulation Applications, In Proceedings of the 2003 Winter Simulation Conference, ed. S. Chick, P. J. Sanchez, D. Ferrin, and D. J. Morrice, 1217-1224. Piscataway, New Jersey: Institute of Electrical and Electronics Engineers, Inc.

Seppanen, M. S. 2005. Operator - Paced Assembly Line Simulation. In Proceedings of the 2005 Winter Simulation Conference, ed. M. E. Kuhl, N. M. Steiger, F. B. Armstrong, and J. A. Joines, 1343-1349. Piscataway, New Jersey: Institute of Electrical and Electronics Engineers, Inc.

Sharda, B., and S. J. Bury. 2008. A Discrete Event Simulation Model for Reliability Modeling of a Chemical Plant, In Proceedings of the 2008 Winter Simulation Conference, ed. S. J. Mason, R. R. Hill, L. Monch, O. Rose, T. Jefferson, J. W. Fowler, 1736-1740. Piscataway, New Jersey: Institute of Electrical and Electronics Engineers, Inc.

Vasudevan, K. K., R. Lote, E. J. Williams, and O. Ulgen. 2008. Iterative Use of Simulation and Schduling Methodologies to Improve Productivity, In Proceedings of the 2008 Winter Simulation Conference, ed. S. J. Mason, R. R. Hill, L. Monch, O. Rose, T. Jefferson, J. W. Fowler, 1896-1903. Piscataway, New Jersey: Institute of Electrical and Electronics Engineers, Inc.

Yang, Z., Q. Chang,, D. Djurdjanovic, J. Ni, and J. Lee. 2007. Maintenance Priority Assignment Utilizing On-line Production Information, Journal of Manufacturing and Science Engineering, ASME, April 2007, Vol.129, 435-446

\section{AUTHOR BIOGRAPHIES}

GONCA ALTUGER is currently a Ph.D. Candidate in the Mechanical Engineering Department at Stevens Institute of Technology. She received an undergraduate degree in Mechanical Engineering from EOU Turkey and a Master's degree in Mechanical Engineering from Stevens Institute of Technology. Her research focus is on knowledge-based intelligent design and production systems. Her email is <galtugerestevens. edu $>$.

CONSTANTIN CHASSAPIS is a Professor and the Director of the Mechanical Engineering Department at Stevens Institute of Technology. His research interests are in knowledge-based engineering systems, computer-aided design and manufacturing, as well as in remotely controlled distributed systems. He has been an active member in ASME, and he has received best paper awards from SPE's Injection Molding Division and ASEE, the distinguished Assistant Professor Award at Stevens Institute of Technology, an Honorary Master's Degree from Stevens Institute of Technology, and the Tau Beta Pi Academic Excellence Award. His email is <cchassapestevens . edu>. 